\title{
Leading Cadres' Natural Resources Assets Departure Audit
}

\author{
$\operatorname{Lin} \operatorname{Tian}^{1, a^{*}}$ \\ ${ }^{1}$ Sias International College of Zhengzhou University, zhengzhou China \\ atianlin77@163.com
}

\begin{abstract}
Keywords: Natural resources; Departure audit; A balance sheet of natural resources; Economic responsibility audit
\end{abstract}

\begin{abstract}
The third Plenary Session of 18th Communist Party of China Central Committee put forward strengthening the leading cadres to strengthen the construction of ecological civilization, promoting the establishment of the responsibility system of responsibility for environmental damage, promoting the development of economic and social sciences, sustainable development of major initiatives. Natural resource assets departure audit, whether it is theoretical or practical community are not a consensus. At the time, the paper, from the natural resources and the concept of natural resource assets ,starting a detailed exposition of the legal basis of natural resource assets audit, the relationship between natural resource assets departure audit and economic responsibility audit, the construction of natural resource balance sheet, the audit of natural resource assets departure and the realistic choice of carrying out the auditing of natural resources assets, in order to reach a consensus, and to promote the socialist theory of audit with Chinese characteristics continue to enrich and perfect..
\end{abstract}

\section{Natural Resources and Basic Properties}

Natural Resources Meaning. The United Nations Environment Program on natural resources are defined as: natural factors and conditions that at a given time and place, can generate economic value to enhance the present and future welfare of mankind. Encyclopedia of the United Kingdom of natural resources defined as: the natural products that can be used by humans and the environmental capacity to generate them. The Encyclopedia of Great Britain defines natural resources as the natural products available to mankind, and the environmental capacity as a source of these ingredients. The former, such as land, water, atmosphere, shale, minerals, and its clusters of forest, the playground, deposit, land, sea, etc.; The latter, such as solar energy, the cycle of geophysical function, the circulation of the ecology function, the geochemical circulation function and so on. The encyclopedia of China defines natural resources as the sources of means of production and subsistence, including land resources, water resources, biological resources, climate resources, tourism resources.

In brief, natural resources can be described as the source of the wealth that exists in its natural form or the naturally occurring substances and energy that humans can use. At the same time, it can also be regarded as "the natural environment factors and conditions that can generate economic value at a certain time, place and condition to enhance the present and future welfare of mankind".

\section{Properties}

(1) "Validity". With "useful" natural elements are the most essential attribute of natural resources.

(2)"Controllability". Only natural elements within the maneuverable range of human beings can be called natural resources. At a certain stage of social development, beyond the technical or economic capacity of the time, or only natural elements not accepted by laws, regulations or religious beliefs, only can be regarded as natural conditions instead of natural resources. From which it is not difficult to see the natural resources belong to the category of history, with the advance of science and technology, economy, system improvement, etc., the extension of natural resources will be expanding.

(3)"Regional". Because the distribution of natural resources has a significant regional characteristic, water resources with basin-wide, plant resources are quite zonal, mineral resources, mining belt. This determines that the development, utilization and protection of natural resources such as control 
measures must also be flexible and diverse, eclectic, to take measures to local conditions to be standardized management.

(4)"system". Natural resources are not isolated, they form complex system of natural resources, connect each other and interact, agricultural soil and water resources and mineral balance in the symbiosis of the associated phenomena, are typical of the system. Are the typical embodiment of the system, which determines the development and utilization of natural resources and protection must adhere to the system of thinking, not just say the water, soil, or mine, forest.

(5)"Renewable". That is, the natural resources are renewed in different degrees by physical effects (gravity, sedimentation, etc.), chemical action, biological action (digestion, transformation, photosynthesis) and human intervention, etc., and updated relatively to human life Resources, known as renewable resources, such as forests, surface water resources, otherwise called non-renewable resources, such as mineral resources.

(6)"Timely". Category of natural resources with changing human awareness, skills development, generally showed a trend of expanding. At the same time, from the time of natural resources, some resources are not changing over time, such as mineral resources; some resources there is a very short time, such as light, wind and other resources, the former known as the constant resources, while the latter known as the flow of resources. Constant resources, as far as possible to control the speed of development and utilization, and the flow of resources are often to be developed as quickly as possible.

\section{The Connotation of Natural Resource Assets}

The Meaning of Natural Resource Assets. Natural resources assets, refers to the existence of natural resources, physical assets. Natural resources assets should first meet the accounting standards on the concept of assets, that is, the formation of past transactions and events, owned or controlled by a subject, is expected to lead to economic interests into the enterprise resources. Natural resources want to become a natural resource asset, must have the characteristics: (1) Scarcity. This is the basic condition for natural resources to become natural resource assets. Those who are not scarce, is not a strict sense of the natural resources assets. Of course, the natural resources themselves must be scarce. (2) Natural attribution. Natural resource assets are not assets owned by corporate accounting, nor are they formed through past transactions or events, but because the nature of our country determines that the natural right of ownership belongs to the state. Therefore, natural resource assets, refers to the scarcity of various natural resources are owned or controlled by the state or collectively, is expected to bring benefits to human society.

The Attributes of Natural Resources Assets. Natural resources Assets is a natural state (including artificial state) of the assets, which are different from fixed assets such as buildings and transportation equipment. Natural resources such as water, forests, mountains, grasslands, wastelands, its characteristics: (1) Basic. Natural resource assets relate to the survival and development of a country, a nation or region and are related to national security. (2) Some natural resources assets belong to public assets are not exclusive, some of them are not public assets and the use of them is exclusive. (3) Rigid demand. The natural resources assets belong to the basic assets, which is the basis of the survival and development of human society, determines the rigid principle of social demand. (4) To restore the original appearance. Due to the past understanding of the bias, take it for granted that the use of resources in any case will not be depleted, followed by wanton waste, resulting in a great waste of resources in exchange for the one-sided GDP development. As the result, we should strive to reduce environmental pollution and excessive use of resources. If possible, bring back the beauty of ecological to the maximum extent in order to sustain socio-economic development.

\section{Natural Resource Assets and Natural Resource}

The Connection between the Natural Resource Assets and Natural Resources. Natural resource assets originate from natural resources, and there are no natural resource assets without natural 
resources. The functions and attributes of natural resources are the basis of the functions and attributes of natural resource assets.

The Distinction between Natural Resource Assets and Natural Resources. (1) In terms of the extension of natural resources, natural resources include more contents than natural resource assets. Natural resources can only become natural resource assets if they satisfy certain conditions.

(2) Natural resource assets belong to the category of social system, and natural resources belong to material category. From the point of view of political economy and superstructure, natural resources determine the natural resources. If there are no abnormal phenomena in natural resources development process, such as waste of resources, depletion of resources, serious damage to resources, etc., When the economic base shakes in the process of social development, the state must formulate relevant rules and regulations from a strategic height, do a good job of top-level design to ensure the healthy operation of the economy.

\section{Legal Basis for Audit of Natural Resource Assets}

Legal Provisions on Natural Resources Assets Audit. Article 91 of the Constitution of the People's Republic of China stipulates that the State Council shall establish an auditing organ to audit and supervise the financial revenues and expenditures of the State Council departments and local governments, and the financial revenues and expenditures of the state's financial institutions and enterprises. The auditing organs shall, under the leadership of the Premier of the State Council, exercise the right of independent auditing and supervision in accordance with the law, and shall not be interfered by other administrative organs, social organizations or individuals. Article 109 provides that: local people's governments at or above the county level to set up auditing organs. Auditing organs at all levels shall independently exercise the power of auditing and supervision in accordance with the law, and shall be responsible to the people 's governments at the same level and the auditing organs at the next higher level. Although there is no explicit requirement that the auditing authorities should audit the relevant natural resources assets, the natural resources assets owned by the state naturally based on the essential reason of the audit - entrusted fiduciary relationship, which is bound to the natural resources assets entrusted by the management of financial revenue and expenditure, economic responsibility, performance audits.

Administrative Regulations on Audit of Natural Resources Assets. "The party and government leading cadres and state-owned enterprise leaders of economic responsibility audit provisions of the implementation details" the thirteenth rule 7 paragraph: "the development and utilization of natural resources and protection of assets, ecological and environmental protection and improvement of the people's livelihood. And clearly defined the natural resources assets must be included in the scope of economic responsibility audit, which laid a solid foundation for audit institutions to carry out audit of natural resources assets.

Provisions on Audit of Natural Resources Assets. In 1998, the Audit Commission established the Agriculture and Resources Environmental Audit Department, started the practice and exploration of natural resource assets and environmental auditing, and carried out a large number of special audit or audit investigation with funds as the main line. "Audit 2008-2012 Audit Development Plan " clearly the resource and environmental audit as one of the six types of audit, marking the resource and environment audit has become an independent practice system.

The Audit Opinions on Strengthening the Audit of Resources and Environment" stipulates that the main tasks of the resource and environment audit are to examine the implementation of the environmental policies and regulations and the implementation of the strategic plan, analyze the performance of the government, and promote the implementation of relevant policies and policies. Standardize the development and utilization of resources management and environmental protection work behavior; The second is to check the resources of environmental funds collection, distribution, use and management, exposing the problems of the existence of evasion, misappropriation, loss and waste, etc., analysis and evaluation of environmental resources, to promote the standardization of fund management and improve the efficiency of the use of funds; The third is to check the resources and 
environment related projects in the construction and operation results, reveal and investigate the development and utilization of resources management and environmental protection in the waste of resources, damage to the environment, loss of assets and other issues ,in order to enhance the resources and environmental management and safeguard national resources and environmental security.

"Audit" Twelfth Five-Year "audit development plan," Article 9 provides that: resource and environmental audit to promote the implementation of resource conservation and environmental protection of the basic national policy as the goal, to check the national resource and environmental policies and regulations to implement, the use of funds allocation management and resource environmental protection project construction and operation, maintenance of resources and environmental safety, to play the audit in resource management and environmental protection in an active role in promoting the construction of ecological civilization. We will strengthen the audit on the protection, development and utilization of important resources such as land, minerals, fresh water and oceans, expose and investigate the problems of illegal selling, disorderly development, inefficient use, destruction of wasteful resources, loss of state-owned resources and resource security. Strengthen the protection and rational utilization of resources according to law; Strengthen the audit of the prevention and control of pollution of water, atmosphere, soil, heavy metal, solid waste, nuclear energy utilization, etc., and uncover and investigate the prevention and control of the pollution Problems, promote the strengthening of pollution prevention and control, and continuously improve the environmental quality; Strengthen the forest, wetland, grassland, biological and other key ecological system protection and desertification control, soil and water conservation, prevention and control of rocky desertification and other ecological, Promote the construction of ecological environment; Strengthen the allocation of energy-saving emission reduction funds, management, use and implementation of relevant policies and regulations audit, expose and investigate the implementation of energy-saving emission reduction policies and regulations are not in place, eliminate backward production capacity, to promote the transformation of economic development, optimize the industrial structure. Audit from the operational level of the proposed natural resource asset audit to carry out more operational provisions, and guide the audit staff how to carry out natural resource asset audit.

Other Relevant Regulations. On December 12, 2013, the Decision of the Central Committee of the Communist Party of China on Several Major Issues on Deepening the Reform was adopted by the Third Plenary Session of the 18th Central Committee of the Communist Party of China, which put forward the" exploring the preparation of natural resources balance sheet, auditing of leading cadres implement natural resource assets, establishing liability for ecological damage investigation system for life" requirements". Released on April 25,2015, the CPC Central Committee and the State Council on accelerating the construction of ecological civilization, natural resource assets were discussed, especially the property rights system of natural resource assets, natural resources management system, natural resource assets on the balance sheet, audit of natural resources assets departure. From the central level proposed the concept of natural resource assets audit, which is what we usually refer to the central from the top design sketches the natural resources asset audit grand blueprint, which is a system of environmental audit innovation for the audit staff development the new field of resource and environmental audit, is bound to inspire the audit staff to carry out the audit of natural resources assets departure theory and practice.

Local Laws and Regulations on the Natural Resource Assets Departure to Carry Out the Relevant Provisions of the Audit. March 2014, Shandong Provincial Audit Office carried out with a focus on marine resources natural resources assets departure auditing pilot work. Zhuhai Municipal People's Congress Standing Committee of Guangdong Province in 2014 adopted the "Zhuhai Special Economic Zone to promote the construction of ecological civilization regulations." The "Regulations" is the 18th National Congress of the first ecological civilization construction of local laws and regulations will be March 1, 2014 officially implemented. "Regulations" for the first time in the legislation provides that the completion of the construction of ecological civilization binding targets, the responsibility of the unit responsible for the first annual assessment shall not be identified as excellent, competent level. "Regulations" is also clear that the gradually established to prepare natural resources balance sheet, 
natural resources assets departure auditing system for leading cadres. We believe that, under the guidance of the central top-level design, the relevant local government audit agencies work together to carry out the audit of natural resources assets through the pilot, and gradually explore, is bound to accumulate more practical experience about audit of resource natural assets.

\section{Relationship between Natural Resource Assets Departure Audit and Economic Responsibility Audit.}

Natural Resources Assets Departure Audit and Traditional Economic Responsibility Audit. The part of natural resource assets departure audit is deriving from the traditional; see the links of two audit indicators. The traditional economic responsibility auditing indicators include: the growth rate of local GDP, the growth rate of fiscal revenue, the rate of population growth, the growth rate of per capita income, the fiscal revenue and expenditure and the local debts (including official hospitality expenses, overseas funds and public vehicle expenses). The state-owned assets value-added indicators, and government investment, and housing, education, social security, employment, medical health and other key people's livelihood expenditure scale and proportion. Auditing of natural resource assets, focusing on the evaluation of the development and utilization of the natural resources assets of leading cadres, such as local economic growth is to be considered in parallel with the economic growth, our expenditure on environment protection, the Green GDP. Therefore, some indicators in the auditing of natural resources assets departure should be carried out drawing on traditional indicators of economic responsibility audit, and they have the same effect on the same index.

Distinction between Natural Resource Assets Departure Audit and Traditional Economic Responsibility Audit. In addition to the evaluation of resources and environmental indicators, the traditional economic responsibility audit indicators include the evaluation indicators of local debt, housing, education, social security, employment, medical and other aspects, but there is little need to quantify and assess these indicators for natural resource assets departure audit. To carry out natural resource assets departure audit, mainly concerned about the government's occupation of natural resources, use, maintenance and management performance and other aspects of control, promote the scientific development of leading cadres to establish the concept of political achievements.

Through analysis of these indicators, to some extent can be considered natural resources asset departure audit is derived from a part of traditional resources economic responsibility audit, but this argument is inevitably biased. Central to the reason why the natural resources assets departure audit to the national strategic level is concerned, is based on the extensive development of China's economy today, the environment has become one of the bottlenecks restricting China's economic development. We need to carry out targeted research on natural resource assets departure audit, forming a complete set of theory of natural resource assets departure audit with Chinese characteristics, so as to carry out the audit of natural resources assets departure, leading the relevant leading cadres to establish a correct view of performance. To change the past one-sided view of GDP. Set up of sustainable and green GDP Outlook laid some foundation for

Achieving sustainable economic development, to avoid the early use of future generations of resources exclusive rights. And the audit theory

System in the field should be distinguished from traditional economic responsibility audit theory.

When leading cadres leave office, the auditing of natural resources assets should be pay more attention, and can influence the mode of regional economic development to a certain extent, and leading cadres will not pursue GDP again blindly, they will also take into account the sustainable development of regional economy and society. As a result, regional growth is more focused on achieving green, sustainable social benefits of GDP.

\section{Balance sheet of Natural Resources Building}

The traditional financial statement auditing, which is based on the financial statements as the object of the audit, is a process of making conclusions and issuing audit opinions for the statements reflect the 
financial position, operating results and cash flow. As a natural resource asset audit, not necessarily strictly in accordance with the traditional financial statements to carry out, but on the natural resource assets of the composition and changes should be reflected in the natural resource balance sheet, thus it is necessary to study the composition of the balance sheet of natural resources. According to the traditional balance sheet, the balance sheet of natural resources consists of natural resource assets, natural resource liabilities, natural resource rights and interests.

Definition of Natural Resource Assets. Natural resources can only become natural resource assets if they meet the following criteria. First, a particular subject owns or controls; Second, can be measured in money; Third, the potential for future benefits and the capitalization of measures to reduce the impact of the subject on natural resources.

Most of natural resources exist in nature in an objective form, people through the production of labor, with the aid of labor tools on the object of labor, and then understanding, use and protection of natural resources, and make it use value.

Definition of Natural Resource Liabilities. Natural resource liability is a realistic obligation for a given entity to manage the ecosystem or restore the state of natural resources and is required to pay future costs or to recover costs, which is expected to result in an outflow of economic benefits.

Definition of Natural Resource Rights and Interests. Natural resource interests consist primarily of natural resource capital, natural resource protection funds and natural resource profits carried over from natural resources. Natural resources capital is the natural rights of the country because of its natural right to the formation of national rights and interests; environmental protection fund is extracted from after-tax profits with earmarked capital, the nature is the same as the surplus reserve in corporate accounting.

Although the three statements of the balance sheet of natural resources are defined, it is still difficult to determine the items included in each statement element. due to the balance sheet is still in the early stages of

Natural resources, whether in theory or practice, did not reach a consensus, there is no better experience to learn from. However, drawing on the accounting standards of enterprises on the balance sheet meaning, it is easy to see that the natural resource balance sheet is a specific entity to reflect a particular date of natural resources, assets and liabilities and the status of the owner's statement. According to China's relevant system, China's natural resources mainly include land resources, water resources, air resources, forest resources, grassland resources, marine resources, mineral resources, wildlife resources. In accordance with the "Assets = Liabilities + Owner's equity" equation, the balance sheet of natural resources should be roughly divided into left and right sides. The main categories of natural resource assets listed above are listed on the left, the top right listed natural resource liabilities, the bottom right shows natural resource interests (including natural resource capital, environmental funds, and so on.).

\section{The Content of Leading Cadres of Natural Resources Assets Departure Audit.}

Leading cadre's natural resources assets leaving audit is a new form of audit, is the integration of traditional environmental audit and economic responsibility, therefore the contents of the leading cadres of natural resources assets departure audit will certainly learn from the traditional financial and financial revenue and expenditure audit, performance audit, the report of the legal compliance audit. Based on the content of traditional audit, combined with the special object of natural resource assets departure audit, the author tried to outline the main content of natural resource assets audit through table 1natural resources assets economic responsibility auditing, table 2 natural resources assets departure auditing contents and table 3 performances evaluation examples of natural resources assets, to better guide the natural resources assets auditing practice. 
Table 1 List of Economic Responsibility of Natural Resources Asset

\begin{tabular}{|c|c|c|}
\hline Department & Administrative responsibility & Asset Management Responsibilities \\
\hline $\begin{array}{l}\text { National } \\
\text { Developmen } \\
t \text { and } \\
\text { Reform } \\
\text { Commission }\end{array}$ & $\begin{array}{l}\text { regional planning and management, the planning and } \\
\text { management of the main functional areas, the } \\
\text { development of circular economy, response to changes } \\
\text { in the future, energy saving and emission reduction } \\
\text { planning and policy implementation, the planning } \\
\text { coordination of land, resources and environmental } \\
\text { protection and review management. }\end{array}$ & $\begin{array}{l}\text { Resource price management, carbon } \\
\text { trading }\end{array}$ \\
\hline $\begin{array}{l}\text { Ministry of } \\
\text { Land and } \\
\text { Resources }\end{array}$ & $\begin{array}{l}\text { Land use control and arable land protection, } \\
\text { geological exploration, mining, mineral processing } \\
\text { and other development activities of the supervision } \\
\text { and management, geological environment protection } \\
\text { and mine ecological restoration }\end{array}$ & $\begin{array}{l}\text { State-owned and collective land } \\
\text { property rights registration and } \\
\text { certificates issued,collective land } \\
\text { expropriation and building land } \\
\text { transfer exploration rights, mining } \\
\text { rights and certificates of registration } \\
\text { issued, transfer of mineral } \\
\text { exploration right or mining right } \\
\text { transfer }\end{array}$ \\
\hline $\begin{array}{l}\text { Ministry of } \\
\text { Agriculture }\end{array}$ & $\begin{array}{l}\text { Farmland protection, agro-ecological environment } \\
\text { monitoring and management, eco-agriculture } \\
\text { inspection, agricultural waste recycling, planning and } \\
\text { management of grassland ecology and aquatic } \\
\text { ecological conservation and so on. }\end{array}$ & $\begin{array}{l}\text { Rural land (including grassland) } \\
\text { contract management contract, } \\
\text { fishery resources management }\end{array}$ \\
\hline $\begin{array}{l}\text { Ministry of } \\
\text { Water } \\
\text { Resources }\end{array}$ & $\begin{array}{l}\text { Water resources planning and management, protection } \\
\text { of } \\
\text { water resources and the planning and management of } \\
\text { soil and water conservation }\end{array}$ & $\begin{array}{l}\text { Water abstraction permit } \\
\text { management and water resources } \\
\text { collection management, water price } \\
\text { management, water price trading }\end{array}$ \\
\hline $\begin{array}{l}\text { State } \\
\text { Forestry } \\
\text { Administrati } \\
\text { on }\end{array}$ & $\begin{array}{l}\text { Forest, wetland ecosystem and wildlife protection and } \\
\text { management, desertification control }\end{array}$ & $\begin{array}{l}\text { Forest right registration (being } \\
\text { transferred to the Ministry of Land } \\
\text { and Resources unified registration) } \\
\text { and the issuance of certificates, rural } \\
\text { forest land contract management, } \\
\text { state-owned forestry and forest } \\
\text { resource management }\end{array}$ \\
\hline $\begin{array}{l}\text { State } \\
\text { Oceanic } \\
\text { Administrati } \\
\text { on }\end{array}$ & $\begin{array}{l}\text { Marine functional zoning, marine use, island } \\
\text { protection and marine environmental investigation, } \\
\text { testing, supervision and management, and marine } \\
\text { resources protection, marine engineering pollution } \\
\text { prevention and control }\end{array}$ & $\begin{array}{l}\text { Registration and certificate issuance } \\
\text { of sea area use right, approval and } \\
\text { assignment of sea area right of use, } \\
\text { management of collection and use of } \\
\text { sea area use fees }\end{array}$ \\
\hline
\end{tabular}

Since the natural resource assets departure audit and the traditional economic responsibility audit exist inextricably linked, so the natural resource assets departure audit should also audit on the financial revenue and expenditure, legal compliance and performance. We can see the Table 
Table2 The contents of natural resources assets departure audit

\begin{tabular}{|c|c|c|}
\hline Types & Audit objectives & Specific audit content \\
\hline $\begin{array}{l}\text { Audit of } \\
\text { financial } \\
\text { revenue and } \\
\text { expenditure }\end{array}$ & $\begin{array}{l}\text { To examine and evaluate } \\
\text { the authenticity and } \\
\text { legitimacy of the financial } \\
\text { funds ; } \\
\text { The authenticity, accuracy } \\
\text { and completeness of } \\
\text { information on natural } \\
\text { resource assets shall be } \\
\text { checked and evaluated. }\end{array}$ & $\begin{array}{l}\text { Check the legitimacy of the funds, funds under } \\
\text { budgetary management of natural resources; } \\
\text { Check whether natural resource allocation is in place, whether } \\
\text { funds are growing, and whether funds are used in line with } \\
\text { budget targets; } \\
\text { Examine whether natural resource funds are used for natural } \\
\text { resource projects in accordance with progress funds; } \\
\text { To check the authenticity, accuracy and completeness of the } \\
\text { natural resource balance sheet and other information compiled } \\
\text { by local governments. }\end{array}$ \\
\hline $\begin{array}{l}\text { Compliance } \\
\text { auditing }\end{array}$ & $\begin{array}{l}\text { To inspect and evaluate the } \\
\text { compliance or } \\
\text { implementation of laws, } \\
\text { regulations and policies of } \\
\text { natural resources of } \\
\text { leading cadre }\end{array}$ & $\begin{array}{l}\text { Inspection and evaluation of the degree of leading cadres to } \\
\text { follow the natural resources laws and regulations; } \\
\text { Inspection and evaluation on ecological protection of the } \\
\text { leading cadres "red lines", clean production, energy saving and } \\
\text { emission reduction, returning farmland to forests; } \\
\text { Inspection and evaluation of leading cadres establishing the } \\
\text { natural resources assets regulation and internal controls; } \\
\text { Inspect and disclose significant dereliction of duty, } \\
\text { malfeasance and corruption related to natural resource assets } \\
\text { by leading cadres. }\end{array}$ \\
\hline $\begin{array}{l}\text { Performance } \\
\text { audit }\end{array}$ & $\begin{array}{l}\text { To inspect and evaluate the } \\
\text { economic and social } \\
\text { benefits and ecological } \\
\text { benefits of the leading } \\
\text { cadres in fulfilling the } \\
\text { ownership responsibility } \\
\text { of the natural resources } \\
\text { assets and the public } \\
\text { management duties. }\end{array}$ & $\begin{array}{l}\text { Inspection and evaluation of the economic performance of } \\
\text { natural resources assets, including natural resource assets } \\
\text { development activities, recycling activities, conservation and } \\
\text { recovery activities of the cost savings and efficiency, the } \\
\text { preservation and appreciation of natural resources assets; } \\
\text { To evaluate and evaluate the social benefits of natural resources } \\
\text { assets, including promoting employment, reducing poverty, } \\
\text { ensuring fair access to natural resources development and } \\
\text { utilization rights by enterprises and individuals, and } \\
\text { maintaining resource security and social stability; } \\
\text { To evaluate and evaluate the ecological benefits of } \\
\text { natural resources assets, including improvement of } \\
\text { ecological environment, reduction of environment pollution, } \\
\text { maintenance of biological diversity, improvement of national } \\
\text { physical and health levels, during the term of office of leading } \\
\text { cadres. }\end{array}$ \\
\hline
\end{tabular}

In the natural resource assets audit process, should focus on natural resource assets performance evaluation. Performance indicators should be designed to:(1) Indicators moderate, to avoid excessive evaluation index, to avoid poor evaluation of indicators;(2) Clear indicators, easy to understand and collect evidence to be verified;(3) Attention to regional and the effectiveness of natural resources because of its wide geographical distribution and uneven, the same indicator due to different location or the environment in which the evaluation should also be differentiated. 
Table 3 Performance Appraisal Index of Natural Resources Assets

\begin{tabular}{|c|c|}
\hline Types & Examples of performance measurement indicators \\
\hline Land resources & $\begin{array}{l}\text { Per capita arable land area, ratio of cultivated land area to cultivated land area, } \\
\text { ratio of medium and low yield area to total cultivated land area, average } \\
\text { content of soil organic matter, soil and water loss rate, desertification rate and } \\
\text { salinization rate }\end{array}$ \\
\hline Water resources & $\begin{array}{l}\text { Per capita water resources, water consumption per unit of land area, water } \\
\text { consumption per unit of industrial added value, water consumption per unit } \\
\text { of GDP, water quality compliance rate of urban water environment functional } \\
\text { areas, water quality compliance rate of backbone waterways, urban sewage } \\
\text { treatment rate }\end{array}$ \\
\hline Atmosphere resources & $\begin{array}{l}\text { Urban air quality good rate, Emission of industrial waste gas, per capita SO2 } \\
\text { emission, sulfur dioxide emission density, per capita smoke dust emission, } \\
\text { smoke dust emission density, per capita nitrogen oxide emission, nitrogen } \\
\text { oxide emission, urban environmental air quality and good rate, per capita } \\
\text { industrial emissions, Density, per capita carbon dioxide emissions, carbon } \\
\text { dioxide emissions density }\end{array}$ \\
\hline Forest resources & $\begin{array}{l}\text { Forest coverage, per capita woodland area, per capita standing stock volume, } \\
\text { unit land area, standing stock }\end{array}$ \\
\hline Grassland resources & $\begin{array}{l}\text { Grassland carrying capacity, vegetable garden improvement input, financial } \\
\text { resources degradation degree, grassland animal husbandry production } \\
\text { efficiency, grassland animal husbandry production potential }\end{array}$ \\
\hline Marine resources & $\begin{array}{l}\text { Sea area, coastline coefficient, sea-farming area, the appropriate number of } \\
\text { Bay, offshore oil reserves, marine natural gas reserves, the use of sea area per } \\
\text { unit area of aquatic products, clean sea area of the total area ratio }\end{array}$ \\
\hline Mineral resources & $\begin{array}{l}\text { Comprehensive recovery rate of mineral resources, dilution rate of mineral } \\
\text { exploitation, utilization rate of mineral dressing and smelting, comprehensive } \\
\text { utilization rate of mineral resources, recovery and utilization rate of } \\
\text { secondary resources and mineral reserve rate }\end{array}$ \\
\hline Wildlife resources & $\begin{array}{l}\text { The number of species of wild animals and plants, the proportion of } \\
\text { endangered species of wild animals and plants, the area of wildlife nature } \\
\text { reserves }\end{array}$ \\
\hline
\end{tabular}

\section{Natural Resources Assets Departure Audit Focus}

The main purpose of carrying out the natural resources assets departure audit is to promote the establishment of lifelong accountability system for the damage to the ecological environment responsibility and to urge the leading cadres to fulfill the responsibilities of scientific management of natural resources, formed the achievement outlook of promoting resource conservation and environment protection and in line with development needs of the times. Therefore, the natural resources assets departure audit should focus on the development and utilization of natural resources and protection. The details are shown below. 
Table 4 Natural Resources Assets Departure Audit Focus

\begin{tabular}{|l|l|}
\hline \multicolumn{1}{|c|}{ Types } & \multicolumn{1}{|c|}{ Contents } \\
\hline $\begin{array}{l}\text { Natural resource strategy } \\
\text { formulation and } \\
\text { implementation }\end{array}$ & $\begin{array}{l}\text { Whether the natural resources strategy embody the basic national policy; } \\
\text { Whether the establishment of natural resources protection legal system; } \\
\text { Whether the implementation of a unified management system; Whether the } \\
\text { formation of environmental protection pattern, the industrial structure; } \\
\text { Whether the national economic accounting system include resources saving; } \\
\text { Whether the establishment of resource compensation mechanism. }\end{array}$ \\
\hline $\begin{array}{l}\text { Natural resources policy } \\
\text { implementation }\end{array}$ & $\begin{array}{l}\text { Implementation of the public policy and natural resources planning objectives; } \\
\text { The implementation of ecological protection and restoration system; The } \\
\text { construction of major environmental engineering projects }\end{array}$ \\
\hline $\begin{array}{l}\text { Natural resource } \\
\text { management }\end{array}$ & $\begin{array}{l}\text { Evaluate the effectiveness of resource management tools; Evaluating the } \\
\text { effectiveness of administrative tools for the management of natural resource } \\
\text { assets; Evaluating the effectiveness of legal instruments in natural resource } \\
\text { management; Assessment of the effectiveness of technical means for natural } \\
\text { resource management }\end{array}$ \\
\hline $\begin{array}{l}\text { Significant activities } \\
\text { related to natural } \\
\text { resources }\end{array}$ & $\begin{array}{l}\text { Land resources development and utilization (concerned about the } \\
\text { implementation of land protection responsibility; attention to land resources } \\
\text { development and utilization of legal compliance; concerned about the use of } \\
\text { land-related special fund management and legal compliance); } \\
\text { Water resources development and utilization (concerned about the protection } \\
\text { of river networks and water sources in the region; the effect of } \\
\text { implementation); } \\
\text { Concerned about the implementation of major projects on soil and water } \\
\text { conservation policies; } \\
\text { Paying attention to the exploitation and utilization of mineral resources. }\end{array}$ \\
\hline $\begin{array}{l}\text { Natural resource } \\
\text { utilization performance }\end{array}$ & $\begin{array}{l}\text { Focusing on natural resource policy performance, funds performance, } \\
\text { development and protection performance, using performance and profitability } \\
\text { performance (economy, efficiency and effectiveness) }\end{array}$ \\
\hline
\end{tabular}

\section{An Analysis on the Paths of Leading Cadres' Natural Resources Assets Departure Audit}

At the Third Plenary Session of the 18th CPC Central Committee, the CPC Central Committee put forward the great call of "audit of the natural resources assets departure the post", and the auditing organ must bear the responsibility. Since the audit of natural resource assets of leading cadres is a new field of auditing that integrates environmental auditing and economic responsibility auditing, it is possible to carry out audit of natural resource assets during carrying out economic responsibility auditing and avoid duplicate audits. It is in line with the concept of Audit of Natural Resources Assets Departure modern audit development. 


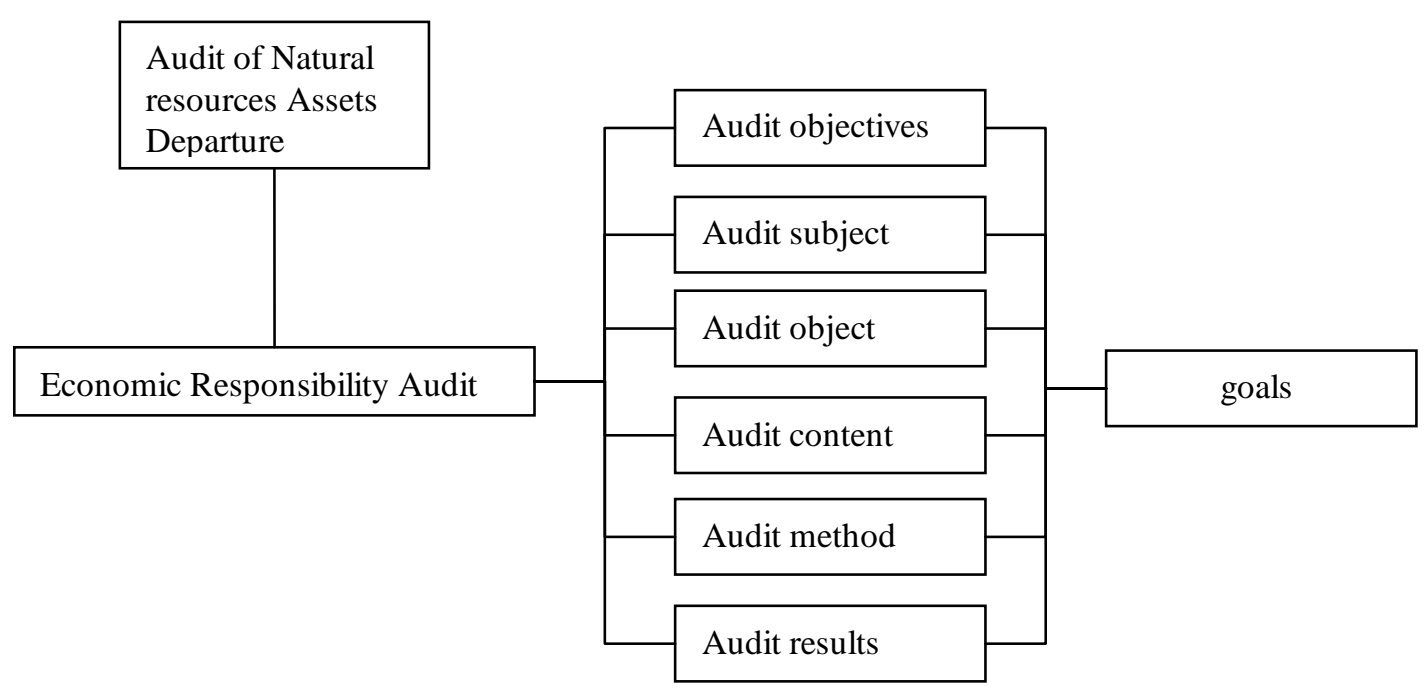

Figure 1. The Audit Implementation Path of Natural Resource Assets

Judging from the audit objectives, there is consistency between them. Economic responsibility audit objectives can promote leading cadres to establish a correct view of power, but one-sided emphasis on GDP growth in the past, natural resources are not included in economic responsibility audit evaluation process. If the economic responsibility evaluation system for leading cadres include natural resources development and protection

the audit objectives of the two have a consistency.

Audit body are unified, two forms of audit subjects are dominated by national audit, social auditing and internal supplement.

Judging from the audit object, both forms of audit include the party and government leading cadres, the object is overlapping.

From the content of audit, the content of economic responsibility audit should be wider than that of natural resource assets. However, both of them pay attention to the exploitation and protection of natural resource assets during the term of office of party and government leaders.

From the audit method, natural resources assets departure audit is a special form of economic responsibility audit, usually taken "superior trial lower" approach.

Judging from the sharing of audit results, whether economic responsibility audit or natural resource assets departure audit, objective and fair audit results are used as one of the criteria for evaluation of cadres reward and punishment.

\section{Conclusion}

From the perspective of natural resources related concept, the paper discusses the legal basis and reality of leading cadres natural resource assets departure audit from the legal level, and compares the difference between leading cadres natural resource assets departure audit and traditional economic responsibility audit from the practical level. The paper expounds the related problems of natural resource balance sheet design, natural resource assets departure audit content, natural resource assets departure audit focus, natural resource assets departure audit implementation path and so on.

\section{References}

[1] Zhang Hong Liang, Liu lian, A Summary of the Symposium on Audit of Natural Resources Assets[J]. Auditing Research, 2014(4). 
[2] Zhang Hongliang, Liu Changcui, A Discussion on Local Leaders' Audit of Natural Resource Assets Departure - Framework Construction and Case [J]. Auditing Research, 2015(5).

[3] Anhui Provincial Audit Office, Reflections on Audit of Natural Resource Assets Departure [J]. Auditing Research, 2014(6).

[4] Chen Xiandong, Reflections on Leading Cadres' Audit of Natural Resource Assets Departure [J]. Auditing Research, 2014(6).

[5] Lin Zhonghua, Discussion on Audit of Leading Cadres' Natural Resources Assets Departure [J]. Auditing Research, 2014(5).

[6] Chen Bo, Discussion on the Auditing of Natural Resource Assets Departure with Property Right Protection [J]. Journal of Audit \& Economics, 2015(5). 